\title{
THE IMPACT OF AERIAL TOPDRESSING ON A MARLBOROUGH HILL COUNTRY FARM
}

\author{
E. SCHERP, Wairau Valley
}

The effects of the aerial sowing of fertiliser and seed have been far-reaching and have had considerable impact on stock and management. The description of these changes and developments can best be given by telling the story of the property and this is done by dealing with it in four parts:

1. Location and description of the property.

2. Topdressing history and present practice.

3. Stock numbers and wool and stock production.

4. Production potential with topdressing and a cattle and sheep association.

\section{THE LOCATION AND DESCRIPTION}

The farm is in the Wairau Valley at Hillersden, Marlborough, about 30 miles from Blenheim and on the southern side of the Wairau River.

The area is 1,740 acres with 190 acres of flat and fairly broken but ploughable terrace and 1,500 acres of fairly steep hill. Rainfall is about 40 in. per annum and summers are dry. Altitude at the homestead is $700 \mathrm{ft}$, rising to $3,400 \mathrm{ft}$ on the hill at the back.

The property is long and narrow in a valley with a narrow and broken floor and fairly steep hill country on either side and extends back five miles from the road frontage with an average width of just over half a mile.

Soil types on the property include: Hororata stony loam on flats, Haldon stony loam on lower hills, and Hurunui stony loam on higher hills.

The soil responds to phosphate. The flat and terraces when broken carry a good pasture. The hill cover in its unimproved state consists of silver tussock, sweet vernal, browntop, and danthonia and there is matagouri in some areas. There is a tendency to reversion to fern and tutu on the shady faces. Some manuka is also present. The hill, particularly on the higher parts, carried practically no clover before treatment.

The farm was bought in 1942, carrying at that time 1,172 sheep without being overstocked. It was regarded in the district as quite a good place. The first job was to improve land near the homestead and this was drained and sown to pasture. In the 1945-46 
season a start was made with land up the gully, starting at the bottom end. Turnips were grown first and approximately 13 to 19 acres were broken in annually. Each year progress was made up the gully until all the area available was brought in and the only extension possible was by adding small areas to paddocks. As a result of this development work sheep numbers increased and 1,500 sheep were shorn in 1950.

All the build-up to that date had been due to cultivation and re-sowing and this now had more or less come to an end, as suitable land for working was restricted. The hill country, however, was undeveloped and had a great potential if it could be developed economically. And now we come to the topdressing:

\section{TOPDRESSING HISTORY AND PRESENT PRACTICE}

In the late $1940 \mathrm{~s}$, small areas of the front hill were topdressed as trials by hand with super and subterranean clover. As results were good, so it was decided to do a large area. Very little aerial topdressing had been done in Marlborough at this time, but it did seem to be an obvious way of getting super and seed on to the hill.

TABLE 1-Topdressing and Oversowing

\begin{tabular}{|c|c|c|c|c|c|c|c|}
\hline & Year & Time & $\begin{array}{r}\text { Approx. } \\
\text { area } \\
\text { acres }\end{array}$ & $\begin{array}{c}\text { Quantity } \\
\text { super } \\
\text { tons }\end{array}$ & $\begin{array}{c}\text { Clover } \\
\text { lb }\end{array}$ & Seed & $\begin{array}{c}\text { Grass } \\
\mathrm{lb}\end{array}$ \\
\hline Stage & 19.50 & Aug & 160 & 10 & - & & - \\
\hline \multirow[t]{4}{*}{ Stage 2} & $1950-51$ & Jan & 1,000 & 100 & $1,400 \mathrm{Sub}$ & & 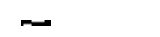 \\
\hline & $19.51-52$ & Jan & 1,300 & 85 & $1,960 \mathrm{Sub}$ & & 7 \\
\hline & $1952-53$ & Jan & 1,000 & 75 & - & 4,00 & $00 \mathrm{lb}$ C'foot \\
\hline & $1953-54$ & $\begin{array}{l}\text { Jan \& } \\
\text { Mar }\end{array}$ & 1.000 & *91 & & & \\
\hline \multirow[t]{8}{*}{ Stage 3} & 3 1954-55 & Jan & 1,740 & 130 & 2,240 Red & & - \\
\hline & $1955-56$ & Jan & 1,740 & 130 & $4,000 \mathrm{Red}$ & 2,24 & $40 \mathrm{lb}$ C'foot \\
\hline & $1956-57$ & Jan & 1,740 & 130 & $\begin{array}{l}1,717 \mathrm{Sub} \\
1,500 \mathrm{w} / \mathrm{c}\end{array}$ & & - \\
\hline & $1957-58$ & Jan & 1,740 & 100 & $1,500 \mathrm{Sub}$ & 8,20 & 00 ryegrass \\
\hline & $1958-59$ & Jan & 1,740 & 100 & - & 2,00 & 00 ryegrass \\
\hline & $1959-60$ & Jan & 1,740 & 100 & 一 & 1,80 & 300 ryegrass \\
\hline & 1960-61 & Jan & 1,740 & 100 & 388 & Cowgras & $s s=$ \\
\hline & 1961-62 & Jan & 1.740 & 100 & $1.505 \mathrm{Co}$ & ownrass & - \\
\hline
\end{tabular}

* Includes 15 tons of molybdic super.

Note: Also in August 1956 a spring sowing of seed was made on the ewe and wether blocks, using 5,000 lb of perennial ryegrass, 1,000 lb of red clover, and 1,000 $\mathrm{lb}$ of $\mathrm{H} 1$ ryegrass.

Note from Table I that in August 1950 a hill block of 160 acres in the front country was topdressed by air with super, but no seed was sown, 
The results again were good. The block had a poor cover of danthonia and browntop and very little while clover. The effect of the topdressing was to stimulate this wild white clover. This was the starting point of the hill country improvement and it became obvious that it would be necessary to include a clover in the aerial sowing,

Note that in the table the topdressing is shown as being in three stages :

Stage 1-Small area treated (starting point) in 1950.

Stage 2-Up to two-thirds of the area of farm treated from 1951 to 1954.

Stage 3-Whole area of farm treated since 1955.

Stage 1 was really experimental and the results were encouraging enough to warrant more topdressing being done. It was proof that the aeroplane was going to be an effective means of getting super on to country not otherwise accessible.

Stage 2 was thus rendered possible when the whole of the property could be treated. As from January 1955 approximately 1,740 acres (whole farm) have been topdressed every year.

\section{Oversowing}

Oversowing has accompanied and has indeed been an essential part of the topdressing programme and was done with sub clover originally, being followed later by cocksfoot, ryegrass, and white and red clover.

The practice of putting in the seed required with each plane load has been found to be the most successful. The seed is put on to the load before it is pushed up by the loader from the heap. During loading the seed gets well mixed and the process seems to be completed by the time it is spread. This system is more successful than pre-mixing the seed with the fertiliser, because if there are hold-ups due to weather, no harm comes to the seed. The actual process of putting seed in with the load is helped by having correctly marked tins so that the right amount of clover or grass seed can be added quickly to each load.

The original oversowing was done with super and sub clover only, this being followed later by oversowing with grasses and other clovers when it was felt that the fertility had been raised sufficiently to give a worthwhile result.

\section{STOCK NUMBERS AND WOOL PRODUCTION}

In this section there are four tables, which deal respectively with: wool weights and sheep shorn; ewes tupped and lambing percentages; sheep sold; and cattle numbers, purchases, and sales.

But first we will look at wool weights. 
TABLE 2-Wool Weights and Averages 1942 to 1962

\begin{tabular}{|c|c|c|c|c|c|c|}
\hline \multicolumn{3}{|l|}{ Season } & \multirow{2}{*}{$\begin{array}{c}\begin{array}{l}\text { No. of } \\
\text { bales }\end{array} \\
\mathbf{2 9}\end{array}$} & \multirow{2}{*}{$\begin{array}{c}\begin{array}{c}\text { Total wool } \\
\text { weight } \\
\text { lb }\end{array} \\
\mathbf{9 , 2 7 2}\end{array}$} & \multicolumn{2}{|c|}{$\begin{array}{l}\text { No. of Average weight } \\
\text { sheep shorn per head }\end{array}$} \\
\hline 1942- 43 & - & & & & 1,172 & 7.91 \\
\hline 1943- 44 & -4- & & 31 & 9,794 & 1,211 & 8.08 \\
\hline $1944-45$ & (.... & & 32 & 9,834 & 1,283 & 7. 68 \\
\hline $1945-46$ & -... & & 38 & 11,975 & 1,377 & 8.69 \\
\hline 1946- 47 & $=4$ & & 44 & 13,081 & 1,423 & 9. 19 \\
\hline $1947-48$ & - & & 44 & 13,894 & 1,463 & 9.49 \\
\hline $1948-49$ & 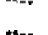 & & 49 & 13.973 & 1462 & 9.55 \\
\hline 1949- 50 & $\ldots$ & & 46 & 14,141 & 1.500 & 9.42 \\
\hline 1950- 51 & 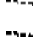 & ... & 47 & 13,995 & 1,568 & 8.92 \\
\hline $1951-52$ & - & "xus & 55 & 17,199 & 1,490 & 11.54 \\
\hline 1952-53 & - & & 61 & 19,902 & 1,717 & 11.5 \\
\hline 1953- 54 & $-\ldots$ & & 61 & 19,456 & 2,037 & 9.55 \\
\hline 1954- 55 & $\cdots$ & & 67 & 21,700 & 2,183 & 9.9 \\
\hline $1955-56$ & $\cdots$ & & 80 & 25,724 & 2,211 & 11.6 \\
\hline 1956- 57 . & . & & 90 & 29,890 & 2,445 & 12.2 \\
\hline 1957- 58 & $-\ldots$ & & 80 & 25,998 & 2,552 & 10.2 \\
\hline 1958- 59 & $\ldots$ & & 83 & 28,307 & 2,685 & 10.5 \\
\hline 1959- 60 & $\cdots$ & & 80 & 27,039 & 2,679 & 10.1 \\
\hline 1960- 61 & 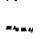 & & 88 & 30,072 & 2,743 & 10.96 \\
\hline 1961-62 & $\ldots$ & & 82 & 29,087 & 2,777 & 10.5 \\
\hline
\end{tabular}

\section{Wbol}

Note that a steady increase in sheep numbers has taken place from 1,172 in 1942-43. The increase of 328 from that date until 1949-50 has been the result of breaking in and developing the valley country. The increase, of 1,277 sheep from 1949-50 is due to a build up on the hills with super and oversowing. Since 1942 the wool clip has risen from approximately 9,000 lb to 29,000 lb and sheep numbers from 1,172 to 2,777 .

Since $1942-43$ it is seen, therefore, that sheep numbers have been more than doubled and wool production trebled. The wool weight per head is a good indication of the feed supply, the weight having risen from about $8 \mathrm{lb}$ per head to 10 or $11 \mathrm{lb}$.

It is of interest to note that breeding ewes comprise only about 30 per cent of the total flock.

At present the flock numbers and classes are (for 196 1-62 shearing) :

870 breeding ewes

$$
\begin{aligned}
& 1,238 \text { dry sheep } \\
& \mathbf{6 4 6} \text { hoggets } \\
& 23 \text { rams }
\end{aligned}
$$

2,777 
The number of ewes mated is limited to the number the paddocks can carry and according to the number which can be looked after properly at lambing time. The lambing percentages are shown in Table 3.

TABLE 3-Lambing Percentages

\begin{tabular}{ccc} 
Year & $\begin{array}{c}\text { Ewes } \\
\text { Tupped }\end{array}$ & Percentages \\
\hline $1950-51$ & 723 & 95.1 \\
$\mathbf{1 9 5 1 - 5 2}$ & 715 & 101.1 \\
$1952-53$ & 778 & 122.8 \\
$1953-54$ & 790 & 123.7 \\
$1954-55$ & 810 & 107.2 \\
$1955-56$ & 820 & 119.6 \\
$1956-57$ & 830 & 115.3 \\
$1957-58$ & 830 & 130.0 \\
$1958-59$ & 825 & 129.0 \\
$1959-60$ & 830 & 122.8 \\
$1960-61$ & 852 & 114.9 \\
$1961-62$ & 876 & 118.6 \\
\hline
\end{tabular}

Over the last 10 years the lambing percentage has averaged 120 per cent. It would be possible to carry ewes on the whole property today, but on the back country close supervision would not be possible and a very much lower lambing percentage would result.

The death rate in the flock is low- 2 to 3 per cent per annum -and is in part due to the high proportion of dry sheep in the flock, these not being so liable to losses as are ewes and lambs. As the ewe flock is concentrated, it can be well shepherded. Also, the carrying of ewes on the back block would add considerably to the labour cost. Wool weights, too, would suffer and so it seems on balance that the present system is the best way to handle the flock.

TABLE 4-Sheep Sold

\begin{tabular}{|c|c|c|c|c|c|}
\hline Year & \multicolumn{4}{|c|}{ No of Sheep } & $\begin{array}{l}\text { No of Sheep } \\
\text { Sold }\end{array}$ \\
\hline $\begin{array}{l}1950-51 \\
1951-52 \\
1952-53\end{array}$ & \multirow{3}{*}{$\cdots$} & \multirow{3}{*}{$\cdots+$} & $\begin{array}{l}693 \\
423 \\
511\end{array}$ & $\begin{array}{l}1956-57 \\
1957-58 \\
1958-59\end{array}$ & $\begin{array}{l}748 \\
842 \\
986\end{array}$ \\
\hline $\begin{array}{c}1953-54 \\
1954-55\end{array}$ & & & $\begin{array}{l}825 \\
643\end{array}$ & $\begin{array}{l}1959-60 \\
1960-61\end{array}$ & $\begin{array}{l}746 \\
760\end{array}$ \\
\hline $1955-56$ & & & 593 & $1961-62$ & 619 \\
\hline
\end{tabular}

Numbers of sheep for sale (see Table 4) arc not high and have not varied greatly, owing to limitation of ewe numbers and the fact that most lambs are required for flock replacement and flock build-up. It is the practice to mate the 5-year ewes with Southdown sires and the resulting lambs are sold fat to the works. 
The cattle story began in 19.56, when it was realised that further means of feed utilisation would be needed, as the sheep had never really caught up with the feed supply. It was seen that cattle numbers would have to be increased and cattle would also have to be put on the back country as here, too, the feed supply was beating the sheep.

Since 1956 the cattle have been increased considerably on the back country, doing a good job in controlling roughage and at the same time continuing to grow well and put on weight.

The following table sets out details of cattle numbers, sales, and purchases.

TABLE 5-Cattle Numbers, Sales, and Purchases

$\begin{array}{lrrr}\text { Year } & \text { Cattle Carried } & \text { Bought } & \text { Sold } \\ 1950-51 & 3 & - & - \\ 1951-52 & 5 & - & 3 \\ 1952-53 & 5 & - & 2 \\ 1953-54 & 3 & - & 1 \\ 1954-55 & 5 & 18 & - \\ 1955-56 & 25 & 51 & 12 \\ 1956-57 & 60 & 62 & 57 \\ 1957-58 & 68 & 60 & 63 \\ 1958-59 & 62 & 159 & 74 \\ 1959-60 & 130 & 65 & 37 \\ 1960-61 & 162 & 112 & 88 \\ 1961-62 & 184 & 63 & 36 \\ 1962-63 & 211 & - & \end{array}$

Beef cattle numbers have risen from none in 1954 to 211 at present, The proportion of cattle to sheep is now 1 to 13 .

The policy is: All cattle are bought in for fattening and in recent years calves have been bought in April-May, wintered on paddocks with some hay, and turned on to the hills in spring.

The cattle will stay on their blocks until fat or nearly fat, which will take one to two years, according to the block and the seasons. If finishing is required, they are brought in to the paddocks and given some extra feed. They are sold mainly on the local market, but an odd truck load goes to Addington.

Dry cattle are carried in preference to breeding cows, owing partly to the topography of the place, as it is a long narrow property with most paddocks bounding on to neighbours' properties; also possibly less labour is required with dry cattle.

\section{THE PRODUCTION POTENTIAL WITH TOPDRESSING AND A SHEEP AND CATTLE ASSOCIATION}

Any statement on potential is no more than a guess, because state of markets as well as production possibilities must be taken into account, since all development, as in the past, will continue to be done out of revenue. 
The meat and wool production per acre over the last few years is as follows:

TABLE 6-M eat and Wool Production

\begin{tabular}{lccccc}
\hline \multicolumn{1}{c}{ Lb per Acre } & $1957-58$ & $1958-59$ & $1959-60$ & $1960-61$ & $1961-62$ \\
\hline Wool & 16 & 18 & 18.6 & 19.8 & 19.1 \\
Lamb & 4.3 & 5 & 4.2 & 4.4 & 4.6 \\
Mutton & 12.3 & 18.5 & 19.8 & 19.8 & 19.4 \\
Beef & 10.5 & 7.5 & 13.2 & 14.4 & 16.5 \\
Total meat & 27.1 & 31 & 37.2 & 38.4 & 40.5 \\
\hline
\end{tabular}

The rate of increase in production is slowing down, although it will still have an upward trend, but may have a different pattern in the future to include more beef.

To refer back to the title of this paper: "The Impact of Aerial Topdressing on a Marlborough Hill Farm". It is obvious that topdressing has played a very big part indeed in developing the farm and its success is due in no small part to the use of the aeroplane as a means of distribution.

We know now that topdressing is very largely beyond the experimental stage, and it is a matter of deciding where it will give best results and how much one can afford to do, but in my opinion we cannot afford NOT to topdress.

We know that problems lie ahead, as markets overseas seem somewhat uncertain; and this, of course, makes for uncertainty in planning farm development, but we really have no option but to go on increasing our production, knowing that our farm production is the source of this country's income, and I am sure that our products will bc needed.

\section{DISCUSSION}

Q. When grass seed and clover are sown from the air what percentage germinates?

A. It is all in the lap of the gods. It all depends on when you sow the seed and the conditions when you get it there. My experience has been a good strikc with sub-clover; with ryegrass and cocksfoot I have not been so successful-probably about 30 per cent germination. But you have to get the grasses there and it is a case of try and try again until you do.

Q. MrScherp said he had come tutu on his farm, what has happened to it? Have you had any trouble with poisoning from it?

A. The tutu is dead. We packed up water on horseback into the area and sprayed with 2-4-5T and made quite a good job. Comment from farmer: I had tutu on my property and hesitated about spraying it, $\mathrm{Tt}$ has disappeared as the result of heavy stocking with cattle. 
Q. Would you give details of additional sub-division; do you consider this an essential part of the developmental programme?

A. The only subdivision has been 100 acres taken off rhe ewe block. I had to make a decision on whether to fence or topdress. One wether block carrying 350 wethers was left as it was and topdressed. Today that block is carrying 1,150 wethers and 70 head of cattle which appear to travel over the whole block. I know this is against all known principles but it was a case of how best to spend the money when comparing financial returns. I had to barb 9 miles of old merino fences and this was done by plane and by pack horse.

Q. (Mr O'Reilly): Mr Scherp is to be congratulated on using subterranean clover. What variety was used? Did white clover take over after a few years of fertility building by the sub-clover?

A. The sub-clover was certified Mt. Barker. In the first year I had an unfortunate experience with it. I was advised to put super out first and then sowed a ton of sub-clover at 5/-per $1 \mathrm{~b}$ and got three rows round the hill. After that I decided that the seed would go in with every plane load of super and 1 got a better spread.

White clover hasn't taken over yet. I think our summers are too dry and the subterranean clover is still holding its own after 12 years.

Q. What is the average cost of super on the ground on your property and what is the usual rate of sowing? According to my calculation about $12 \mathrm{cwt}$ of super has gone over the whole place-is this correct?

A. Cost of super spread by plane is $£ 18$ per ton. It costs $£ 13$ per ton to land super on the place and the plane charges are $\mathbf{E 5}$ per ton.

The rate of sowing has varied. In the early days we had the old Tiger which was very slow and could not reach the back country with 100 tons so we had to double back with this. In 19.56 we used a Cessna plane and for 4 years we put on $1 \frac{1}{2} \mathrm{cwt}$ per acre over the whole property. When the price of wool dropped we brought the rate down to $1 \mathrm{cwt}$ per acre which was 100 tons in all and this rate has been maintained.

Q. Have you any grass grub problems?

A. Yes, like all people who have improved country we have it on the hills. Six years ago it was bad on some of the faces, but I did nothing and for the last 3 or 4 years I haven't seen any of it.

Comment: Have you had a good look?

A. It would show up-l'm certain of that. I haven't used any D.D.T. on the paddocks and I don't think you would find many grub patches on them.

Q. (Visitor from Australia): As a result of the build-up of phosphate do you think you will be able to reduce the rate in future?

A. That is a tough question. The farm has been topdressed for 40 years and I think I shall have to continue putting on $1 \mathrm{cwt}$. per acre to maintain fertility and increase production.

Q. Are you using straight super or sulphurised super?

A. For nine years we used $44 / 46$ super and then after trouble with planes we went over to aerial super for three or four years. I have used no sulphurised super yet but Mr Beggs with trials on my property has just about convinced me that I should use sulphurised super this coming year.

Q. (C. lversen): If you were doing the job over again would you vary the grass sowing? Would you try to get grasses in any earlier?

A. I would be perfectly happy with what I have done. I don't think there would have been enough build up of fertility to get grasses in any earlier. 